\title{
USEFUL IMMUNOHISTOCHEMICAL INDICATORS IN CANINE MAST CELL TUMOURS
}

\author{
Małgorzata KANDEFER-GolA*, Marcin NowAK, Janusz A. MADEJ, Stanisław DzIMIRA, \\ Rafal CIAPUTA and Izabela JANUS \\ ${ }^{1}$ Department of Pathology, Faculty of Veterinary Medicine, Wroclaw University of \\ Environmental and Life Sciences, ul. C. K. Norwida 31, 50-375 Wroclaw, Poland
}

(Received 17 April 2014; accepted 29 October 2014)

\begin{abstract}
Morphological and immunohistochemical analysis of 45 canine mast cell tumours was performed to determine whether the proteins examined are useful for a more precise description of tumour morphology and a more reliable determination of the prognosis in patients. Tissue sections were stained according to the standard haematoxylin and eosin (HE) technique and with toluidine blue to demonstrate cytoplasmic granules. Immunohistochemical studies were performed, using the cell markers CD117 (c-kit), p16 and von Willebrand factor (FVIII). In CD117 three different staining patterns were observed: (1) membranous reaction, (2) intense staining of cytoplasm, and (3) a diffuse, delicate cytoplasmic reaction. Von Willebrand antibody was evaluated on the basis of the number of blood vessels stained. p16 expression was evaluated by scoring positive nuclear reaction. Positive expression was demonstrated for all examined antigens, but their level of expression differed depending on the grades of tumour malignancy. Statistical analysis of the results documented a pronounced positive correlation between the markers studied and the grade of tumour malignancy $(\mathrm{P}<0.001)$. It was shown that each of the cell markers examined represents a useful prognostic indicator for patients with mast cell tumours. The calculated correlation coefficients demonstrate a strong association between the expressions of CD117, FVIII and p16, and the histological malignancy of a tumour.
\end{abstract}

Key words: Mast cell tumour, dog, p16, CD117, FVIII

Mast cell tumours or mastocytomas (MCT) belong to the most frequently diagnosed skin tumours in dogs (Ciaputa et al., 2013). They develop at any age and are independent of the dog's gender. According to Macy (1985), the predisposed breeds include Boxers, Bull Terriers, Labrador Retrievers, Pugs and Boston Terriers. Clinically, mastocytomas exhibit a variable biological behaviour: either individual, benign lesions occasionally infiltrating deeper tissues or multiple, malignant tumours spread throughout the body are noted (Patnaik et al., 1984; Zemke et al., 2001; Hargis and Ginn, 2012). Most frequently, the tumours

*Corresponding author; E-mail: malgorzata.kandefer-gola@up.wroc.pl;

Phone: 0048 (71) 320-5256; Fax: 0048 (71) 320-5414 
are accompanied by dermal erythema, pruritus and oedema (the so-called Darier's sign), imitating inflammatory reaction, which frequently leads to misdiagnosis and erroneously implemented treatment. The phenomenon is linked to mast cell degranulation and release of inflammatory mediators to surrounding tissues (Hargis and Ginn, 2012).

Microscopic evaluation most frequently employs the histological grade of tumour malignancy described by Patnaik et al. in 1984 (Zemke et al., 2001). It is based on the evaluation of tumour invasiveness, the morphology of mast cells and the mitotic index (Table 1). Mast cells manifest a tendency to form larger clumps, and with an increasing grade of histological malignancy they begin to infiltrate deeper tissues. The sublayer of the tumour involves a fibrous or fibrovascular tissue with a tendency for hyalinisation and degeneration of collagen fibres, frequently with infiltration by eosinophils.

\section{Table 1}

Grades of histological malignancy in mast cell tumours according to Patnaik et al. (1984)

\begin{tabular}{|c|c|c|c|c|c|}
\hline \multirow{2}{*}{$\begin{array}{l}\text { Grade } \\
\text { of } \\
\text { malig- } \\
\text { nancy }\end{array}$} & \multicolumn{3}{|c|}{ Cell morphology } & \multirow{2}{*}{ Mitotic index } & \multirow{2}{*}{$\begin{array}{l}\text { Surrounding } \\
\text { tissues }\end{array}$} \\
\hline & Shape & Cytoplasm & Cell nucleus & & \\
\hline $\mathrm{I}$ & round & $\begin{array}{l}\text { high amount } \\
\text { of cytoplasm } \\
\text { with numerous } \\
\text { granules }\end{array}$ & $\begin{array}{l}\text { round with } \\
\text { condensed } \\
\text { chromatin }\end{array}$ & - & $\begin{array}{l}\text { slight oedema } \\
\text { and necrosis }\end{array}$ \\
\hline II & $\begin{array}{l}\text { round to oval, } \\
\text { occasionally } \\
\text { giant or spindle- } \\
\text { shaped }\end{array}$ & $\begin{array}{l}\text { moderate } \\
\text { amount of } \\
\text { cytoplasm with } \\
\text { delicate granules, } \\
\text { occasionally scanty } \\
\text { cytoplasm with large, } \\
\text { hyperchromatic } \\
\text { granules }\end{array}$ & $\begin{array}{l}\text { round, with } \\
\text { loose } \\
\text { karyoplasm } \\
\text { and single } \\
\text { nucleolus, } \\
\text { less frequently } \\
\text { double nuclei }\end{array}$ & $\begin{array}{l}\text { low, } 0-2 \text { per } \\
\text { high power } \\
\text { field }\end{array}$ & $\begin{array}{l}\text { regions of } \\
\text { significant } \\
\text { tissue oedema } \\
\text { and necrosis }\end{array}$ \\
\hline III & $\begin{array}{l}\text { moderate size, } \\
\text { round, oval or } \\
\text { spindle-shaped, } \\
\text { many giant } \\
\text { cells }\end{array}$ & $\begin{array}{l}\text { poorly } \\
\text { distinguished } \\
\text { cytoplasm } \\
\text { containing } \\
\text { poorly visible } \\
\text { or invisible } \\
\text { granules }\end{array}$ & $\begin{array}{l}\text { round, vesicular } \\
\text { cell nucleus } \\
\text { with a single } \\
\text { or multiple } \\
\text { nucleoli, } \\
\text { frequent bi- } \\
\text { or multinuclear } \\
\text { cells }\end{array}$ & $\begin{array}{l}\text { high, 3-6 per } \\
\text { high power } \\
\text { field }\end{array}$ & $\begin{array}{l}\text { frequently } \\
\text { noted: oedema, } \\
\text { congestion } \\
\text { and necrosis }\end{array}$ \\
\hline
\end{tabular}

The aim of this study was to determine the expression of cell markers, including c-kit (CD117), von Willebrand factor (FVIII) and p16, in mast cell tumours of the canine skin. The results have allowed us to determine the morphol- 
ogy of tumours more precisely and to evaluate if the proteins examined are helpful in predicting the prognosis. Especially, the findings disclosed the density and size of blood vessels, which create a network sufficient for the nutrition and oxygenation of the tumour. Furthermore, angiogenesis indicates the growth ability, invasiveness and metastatic potential of tumours. The CD117 staining pattern and the number of labelled nuclei in p16 staining are highly correlated with MCT malignancy. Higher MCT grade and blood vessel density indicate increased malignancy and poorer prognosis. A further objective was to study whether the histological malignancy of tumours observed in haematoxylin and eosin (HE) stained specimens was correlated with the expression of $\mathrm{p} 16$ and CD117 proteins and the number of blood vessels in the tumours.

\section{Materials and methods}

The research was conducted on 45 MCT collected in 2011 at the Department of Pathology, Wrocław University of Environmental and Life Sciences (Wrocław, Poland). The tumours had been excised from dogs of different breeds, sex and age. The studies showed that MCT morbidity reached its peak between 7 and 9 years of age (27 cases), although neoplastic lesions could be detected in animals of various ages (ranging from 2.5 to 14 years), in both sexes (20 female and 25 male dogs were examined). In this study, the highest number of cases were found in American Staffordshire Terriers $(n=8)$, followed by Labrador Retrievers and mongrel dogs $(n=6$ of each), Boxers $(n=5)$, Dachshunds, Golden Retrievers and Bernese Mountain dogs ( $=3$ cases in each breed), while the remaining breeds were represented by single cases.

Tumour fragments were fixed in $7 \%$ buffered formalin for $24 \mathrm{~h}$, then embedded in paraffin blocks. Three to four $\mu \mathrm{m}$ thick paraffin sections were stained with haematoxylin and eosin (HE) and with toluidine blue.

Immunohistochemical studies were performed in 4- $\mu \mathrm{m}$-thick paraffin sections placed on silanised slides. Subsequently the sections were cleared in xylene and passed through a series of alcohols of a decreasing concentration to water. Antigen retrieval was achieved by cooking the slides in citrate buffer $(\mathrm{pH}$ 6.0) at $97^{\circ} \mathrm{C}$ for $20 \mathrm{~min}$. Endogenous peroxidase was blocked in 3\% hydrogen peroxide solution. Subsequently the sections were overlaid with primary antibodies specific for CD117 (Polyclonal Rabbit Anti-Human CD117, c-kit, catalogue no. A4502, diluted 1:100, Dako ${ }^{\circledR}$ ), for von Willebrand factor (FVIII) (Polyclonal Rabbit Anti-Human von Willebrand Factor, catalogue No. A0082, diluted 1:200, $\mathrm{Dako}^{\circledR}$ ) and for p16 (Monoclonal Rabbit Anti-Human Anti-p16/INK4a Antibody, clone EP435Y, diluted 1:200, Merck Millipore). All the specimens were incubated at room temperature for 20 min, then washed in EnVision ${ }^{\mathrm{TM}}$ FLEX Wash Buffer $(20 \times)$. After rinsing them, the sections were overlaid with EnVision ${ }^{\mathrm{TM}}$ 
FLEX/HR visualisation system and incubated at room temperature for $20 \mathrm{~min}$. The immunohistochemical reactions were developed using a solution of 3,3diaminobenzidine tetrahydrochloride (DAB), EnVision ${ }^{\mathrm{TM}}$ FLEX DAB + Chromogen $\left(\right.$ Dako $\left.^{\circledR}\right)$. Finally, the sections were rinsed in distilled water, the cell nuclei were counterstained with haematoxylin and the specimens were dehydrated in a series of alcohols. For every marker studied a positive and a negative control was included. The positive control involved samples of healthy skin and employing all the reagents, while the negative control was prepared with PBS instead of antibodies.

In the detection of CD117 three patterns of colour reaction were distinguished: the first pattern involved a pronounced membranous reaction and in some cells a slight reaction in the cytoplasm, the second pattern was characterised by intense but focal cytoplasmic staining, while the third pattern represented a diffuse, delicate staining of the entire cytoplasm. Each slide was evaluated on the basis of the highest pattern observed in 100 neoplastic cells at the magnification of $\times 400$ (Kiupel et al., 2004). During the statistical analysis the 1st, 2nd and 3 rd pattern staining were used as numerical score.

By immunostaining with von Willebrand factor the stained endothelial cells of blood vessels were examined. Initially, the areas most intensely supplied with blood vessels (so-called 'hot spots') were identified. For each slide, 5 hot spot areas at the magnification of $\times 200$ were chosen. The mean value of the vessel count in those five fields was retained as the final value. The statistical analysis was performed on the number of blood vessels.

Expression of p16 was evaluated using a semiquantitative scale, scoring the positive nuclear reaction $(0-5 \%$ : no reaction $[-], 6-25 \%$ : weak reaction $[+]$, 26-50\%: moderate reaction $[++],>50 \%$ : intense reaction $[+++])$. In each slide 5 randomly selected areas were chosen in which labelled cell nuclei were counted. During the examination, nuclear and infrequently cytoplasmic reactions were observed $(\times 400)$.

Microphotographs of all examined neoplastic lesions were taken using an Olympus BX53 optical microscope (Olympus, Japan), coupled to a ColorView IIIu digital camera (Olympus, Japan).

The results were subjected to statistical analysis using Statistica PL software (StatSoft Polska) including the determination of Spearman's correlation coefficient (rho).

\section{Results}

On the basis of $\mathrm{HE}$ and toluidine blue staining, the tumours were grouped in line with the scale of histological malignancy according to Patnaik et al. (1984): 11 tumours represented an MCT of grade I, 21 of grade II and 13 of grade III (Fig. 1). 


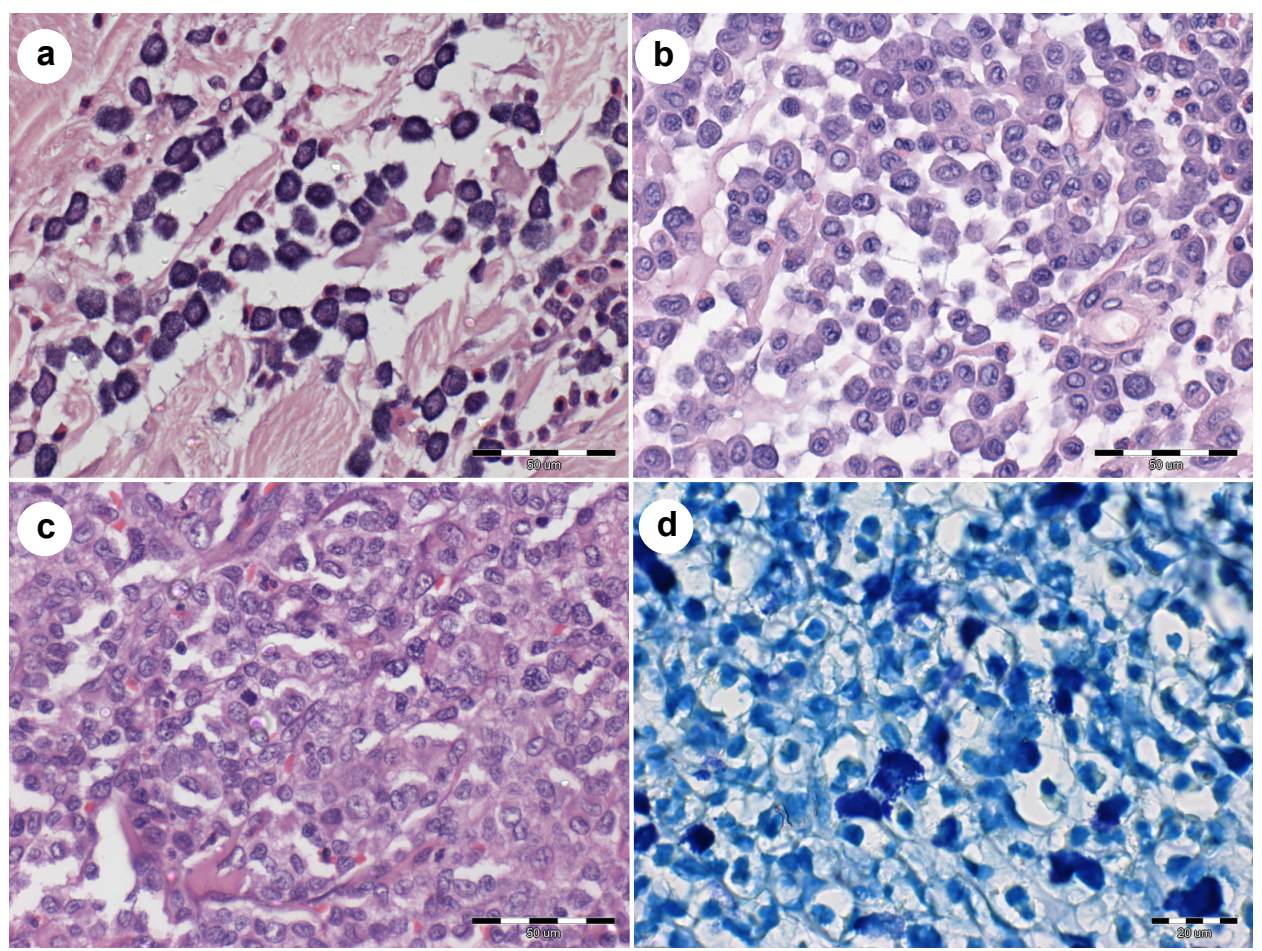

Fig. 1. Mast cell tumour staining with haematoxylin and eosin (HE) $(a-c)$ and toluidine blue $(d)$. $a$. Grade I. Round mast cells with abundant cytoplasm and numerous granules. $\times 400$; $b$. Grade II. Round and oval cells with various amounts of cytoplasm and delicate granules. Some cells contain double nuclei. $\times 400 ; c$. Grade III. Polymorphic cell with no visible cytoplasmic granules. Different size of nuclei and also multinucleated cells. Visible mitotic figures. $\times 400 ; d$. Grade II. Dark violet mast cells granules, visible on blue background. $\times 1000$

In grade I tumours CD117 demonstrated first-pattern staining in 100\% of the lesions. On the average, two blood vessels were noted per visual field, including $18.1 \%$ slides with a single blood vessel, $45.5 \%$ slides with two blood vessels and $36.4 \%$ slides with three blood vessels. Staining for the proliferation marker p16 demonstrated weak $[+]$ reaction in $72.7 \%$ of the cases, and a moderate reaction $[++]$ in $27.3 \%$. In the group studied, no pronounced reaction for $\mathrm{p} 16$ protein $[+++]$ was noted. Mostly a delicate cytoplasmic reaction was observed, with only a few nuclei being stained.

In case of grade II tumours $47.6 \%$ of the lesions manifested the second pattern of staining for CD117, while $38.1 \%$ exhibited the third and $14.3 \%$ the first pattern of staining. On the average, four blood vessels were detected per visual field, including $57.1 \%$ slides with $4,28.6 \%$ with 3 and $14.3 \%$ with 5 blood vessels. In studies for the detection of $\mathrm{p} 16,66.7 \%$ cases manifested a moderate reaction $[++], 23.8 \%$ cases represented a weak reaction $[+]$, and only in $9.5 \%$ 
cases was there a pronounced reaction [+++]. Usually about $35 \%$ of the nuclei were labelled brown, and staining of cytoplasmic location was infrequently observed.

In all $(100 \%)$ grade III cases the third-pattern staining of CD117 was noted. On the average, five blood vessels were detected per visual field, including $61.5 \%$ cases with $5,23.1 \%$ cases with 6 and $15.4 \%$ cases with 4 blood vessels. All the slides demonstrated expression of p16 protein at a high level [+++], and the visual field was dominated by labelled nuclei. The expression of cell markers in different grades of MCT is illustrated in Fig. 2.

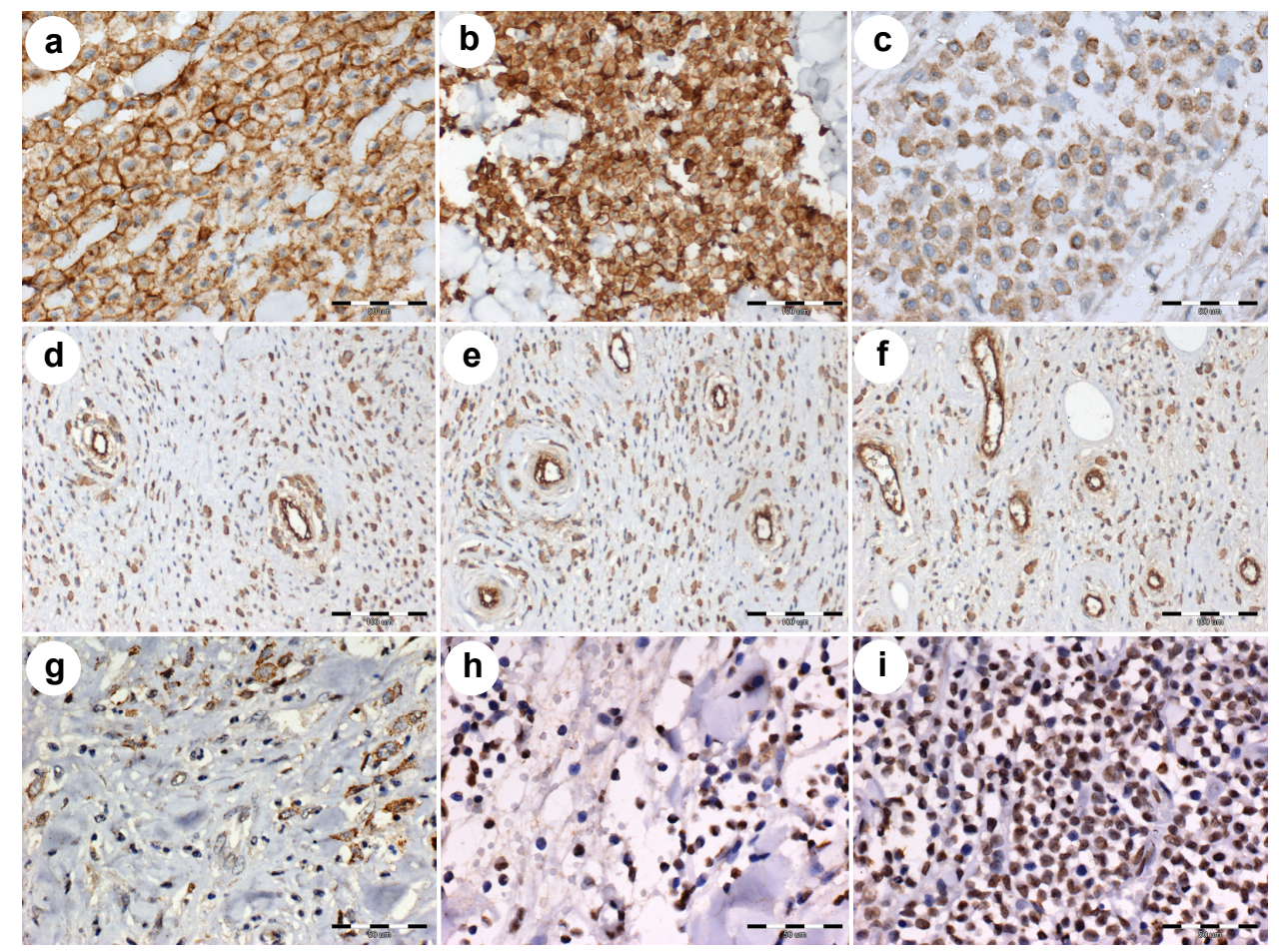

Fig. 2. Staining pattern of examined antibodies in all grades of mast cell tumour. (a-c) CD117 expression pattern was different, depending on malignancy: $a$. Grade I. Pronounced membranous reaction is visible in nearly all cells. $\times 400 ; b$. Grade II. Intense, focal staining of cytoplasm. $\times 200 ; c$ Grade III. Delicate, diffuse staining of cytoplasm. $\times 400 .(d-f)$ von Willebrand factor expression pattern was similar in all cases, the most important difference being in the number of disclosed blood vessels: $d$. Grade I. Two blood vessels are visible. $\times 200$; $e$. Grade II. Five blood vessels are visible. $\times 200 ; f$. Grade III. Seven blood vessels are visible. $\times 200 .(g-i)$ p16 expression, stained nuclei were taken into account: $g$. Grade I. Only few cells presented a nuclear staining pattern, mostly the cytoplasm was labelled. $\times 400 ; h$. Grade II. Immunostained nuclei, cytoplasmic reaction was weaker than in grade I. $\times 400 ; i$. Grade III. In most of the cells nuclear reaction was observed. $\times 400$ 
Statistical analysis of the results demonstrated a statistically significant $(\mathrm{P}<0.001)$ positive correlation between the grade of tumour malignancy determined by HE staining and the expression of CD117, FVIII and p16 proteins, as well as between individual protein pairs. The correlation coefficient (rho, according to Spearman) manifested values $>0.7$ for each pair of staining: HE-CD117: 0.85; HE-FVIII: 0.9; HE-p16: 0.84; CD117-FVIII: 0.89; CD117-p16: 0.72, FVIII-p16: 0.78 . Thus, the results demonstrate a pronounced relationship between the cell markers studied.

\section{Discussion}

Canine mastocytoma represents a tumour that remains to be poorly understood despite its very high incidence. This reflects its variable biological behaviour and incompletely recognised, probably multifactorial aetiology.

The factor, which is responsible for the proliferation, differentiation and degranulation of mast cells, involves the kit ligand and is termed also as mast cell growth factor (MCF) or stem cell factor (SCF). The ligand, located on mast cells, binds to the transmembrane receptor of KIT tyrosine kinase (classified as CD117) (Webster et al., 2006; Passantino et al., 2008). This involves a protein coded by the $c$-kit proto-oncogen. The role of $c$-kit mutation has been emphasised in the aetiology of mastocytoma. As a result of such mutations the KIT receptor becomes stably stimulated even in the absence of the ligand (Kiupel et al., 2004; Morini et al., 2004). Most frequently, mutations of the duplication type (ITD - internal tandem duplication) and deletions of exon 11 are detected (Zemke et al., 2001; Zemke et al., 2002; Webster et al., 2006), but they are present in only $30-50 \%$ of dogs carrying grade II or III mastocytoma (Downing et al., 2002; Zemke et al., 2002). These results indicate that, apart from the mutated c-kit protein, probably also other factors play a significant role in the induction of mast cell tumours; however, the mutations are definitely linked to the histological grade of tumour malignancy.

Our investigations have corroborated the results obtained by the groups of Kiupel, Webster, Zemke and Passantino, which strictly linked the obtained pattern of CD117 staining with the histological malignancy of mastocytoma (Zemke et al., 2001; Kiupel et al., 2004; Webster et al., 2006; Passantino et al., 2008). Moreover, our results have confirmed the observations of Kiupel et al. (2004) and Webster et al. (2006) that the type of reaction pattern makes it possible to predict the probability of tumour progression. Low-grade histological tumour malignancy is mainly linked to the membranous reaction and insignificant staining of the cytoplasm, while high-grade malignancy is usually associated with a diffuse cytoplasmic reaction. Therefore, despite the apparently low or intermediate histological malignancy estimated by HE staining (MCT of grade I or II), occasionally quite distinct results can be obtained in anti-CD117 staining. A pro- 
nounced positive correlation with the grade of histological malignancy has been demonstrated (estimated in HE staining at the level of 0.85) which confirms the important role of the c-kit protein. In studies on grades I and III, $100 \%$ of slides showed the first and the third pattern of staining, respectively. For tumours of grade II malignancy, the results were more divergent: most of the slides manifested the second pattern of staining although reactions of both the first and the third types were detected as well. This is thought to be linked to morphological heterogeneity of the tumours. In the studies of Northrup et al. (2005) and Kiupel et al. (2011) it was shown that subjective evaluation by a pathomorphologist also plays an important role. The highly pronounced correlation between the expressions of CD117 and p16 (0.72) points to a strong relationship between the proteins in MCT. This confirms the earlier drawn conclusions on the strict dependence between the CD117 staining pattern, the higher histological malignancy of the mast cell tumour and a less favourable prognosis.

Neoangiogenesis has a key importance in neoplastic processes. Blood vessels of the tumour manifest a number of abnormalities in both structure and function. The basement membrane and the pericytes may form a few loosely linked layers, in which cells can have an irregular shape. The leaky endothelium gives rise to haemorrhages and facilitates the passage of tumour cells into the circulation (Crivellato et al., 2008). Mast cells show a tendency to accumulate in places of new blood vessel formation. The released mediators control the proliferation and function of endothelial cells (Metcalfe et al., 1997; Crivellato et al., 2008). According to Crivellato et al. (2008), these mediators include VEGF (vascular endothelial growth factor), FGF-2 (fibroblast growth factor-2), TGF- $\beta$ (transforming growth factor- $\beta$ ), TGF- $\alpha$ (tumour necrosis factor- $\alpha$ ), IL-8, MMP-2 (matrix metalloproteinase-2), MMP-9 (matrix metalloproteinase-9), NGF (nerve growth factor), PDGF (plateled-derived growth factor), angiopoietin 1, leptin, adrenomedullin, tryptase, chymase, histamine and heparin. In addition, mediators are produced which aim at the degradation of extracellular matrix (ECM), which facilitates the development of metastases and promotes the angiogenetic process (Baram et al., 2001). Numerous studies have demonstrated that the higher density of blood vessels within MCT is connected with a poorer prognosis (Theoharides and Conti, 2004; Crivellato et al., 2008; Strefezzi et al., 2009).

The present study has corroborated the observations of Ranieri et al. (2003), Preziosi et al. (2004) and Strefezzi et al. (2009) that the number of blood vessels represents an important aspect of malignancy: an increasing grade of histological malignancy of the tumour was accompanied by a growing density of vascular network. Moreover, the statistical analysis of results obtained in the present study has demonstrated a pronounced positive correlation at the level of 0.9 between the grade of malignancy and the expression of FVIII. This confirms that in tumours of a higher malignancy grade the cells are better supplied with blood. Therefore, it can be concluded that such a supply is linked with evident progres- 
sion of the tumour. Statistical analysis has demonstrated a positive correlation at the level of 0.89 between the expressions of FVIII and CD117. The results corroborate the pronounced relationship between the density of blood supply and the pattern of CD117 staining and, thus, the histological grade of tumour malignancy.

The p16 protein, which belongs to the inhibitors of cyclin-dependent kinases, controls the passage of cells from $\mathrm{G}_{1}$ into $\mathrm{S}$ phase and is considered to represent a factor inhibiting the growth of neoplastic cells. Physiologically, expression of the marker is high in currently non-dividing cells and low in intensely dividing cells. Moreover, the protein acts as a controller of tumour cell apoptotic process, in which a decreased expression of p16 induces an increased resistance of cells to apoptosis, which may promote their immortality (Rocco and Sidransky, 2001; Witkiewicz et al., 2011). DeInnocentes et al. (2009) and Witkiewicz et al. (2011) observed an increased expression of p16 in senescent cells, cells with damaged DNA and cells under oncogenic stress. High level of the protein was shown also in certain neoplastic lesions, first of all in those induced by oncogenic viruses as well as in ovarian cancer and in adenocarcinomas of the milk gland (DeInnocentes et al., 2009; Phillips et al., 2009; Witkiewicz et al., 2011). According to DeInnocentes et al. (2009), this is probably linked to genetic mutations of deletion type in the $p 16$ gene. Despite several biochemical and genetic studies, the role of the markers remains to be fully clarified while its increased or decreased expression is probably linked to multiple factors (Rocco and Sidransky, 2001).

In our own studies we have demonstrated a very pronounced reaction $[+++]$ for p16 in all examined grade III cases and a weak reaction in $72.7 \%$ of grade I cases, in which less than $25 \%$ of the cells proved to be positive. Moreover, the statistical analyses have demonstrated a pronounced correlation at the level of 0.84 between the expression of p16 protein and the histological malignancy of tumours evaluated in HE-stained slides. This has allowed us to confirm the suggestion that in mast cell tumours the expression of this marker increases with the grade of histological malignancy. The correlation coefficient between the expression of p16 protein and that of FVIII was found to be 0.78 . The results indicate a strong interrelationship between the two markers studied: accordingly, an increased expression of the p16 protein is associated with both a higher degree of histological malignancy found by HE staining and a higher density of the blood vessel network.

In summary, we can state that each of the cell markers examined represents a useful prognostic indicator for patients with MCT. The calculated correlation coefficients confirm a strong link between the expressions of CD117, FVIII and p16 and the histological malignancy of a tumour. An increased expression of the cell markers studied points to a higher likelihood of progression of dermal mastocytoma in dogs. 


\section{References}

Baram, D., Vaday, G. G., Salamon, P., Drucker, I., Hershkoviz, R. and Mekori, Y. A. (2001): Human mast cells release metalloproteinase- 9 on contact with activated T-cells: juxtacrine regulation by TNF- $\alpha 1$. J. Immunol. 167, 4009-4016.

Ciaputa, R., Kandefer-Gola, M., Nowak, M. and Madej, J. A. (2013): Prevalence of tumours in domestic animals in the Lower Silesia (Poland) in 2009-2011. Bull. Vet. Inst. Puławy 57, 53-59.

Crivellato, E., Nico, B. and Ribatti, D. (2008): Mast cells and tumour angiogenesis: New insight from experimental carcinogenesis. Cancer Lett. 269, 1-6.

DeInnocentes, P., Agarwal, P. and Bird, R. C. (2009): Phenotype-rescue of cyclin-dependent kinase inhibitor p16/INK4A defects in a spontaneous canine cell model of breast cancer. J. Cell Biochem. 106, 491-505.

Downing, S., Chien, M. B., Kass, P. H., Moore, P. E. and London, C. A. (2002): Prevalence and importance of internal tandem duplications in exons 11 and 12 of c-kit in mast cell tumors of dogs. Am. J. Vet. Res. 63, 1718-1723.

Hargis, A. M. and Ginn, P. E. (2012): The integument. In: Zachary, J. F. and McGavin, M. D. (eds) Pathologic Basis of Veterinary Disease. 5th edition. St. Louis, USA. pp. 1082-1084.

Kiupel, M., Webster, J. D., Bailey, K. L., Best, S., DeLay, J., Detrisac, C. J., Fitzgerald, S. D., Gamble, D., Ginn, P. E., Goldschmidt, M. H., Hendrick, M. J., Howerth, E. W., Janovitz, E. B., Langohr, I., Lenz, S. D., Lipscomb, T. P., Miller, M. A., Misdorp, W., Moroff, S., Mullaney, T. P., Neyens, I., O’Toole, D., Ramos-Vara, J., Scase, T. J., Schulman, F. Y., Sledge, D., Smedley, R. C., Smith, K., Snyder, P., Southorn, E., Stedman, N. L., Steficek, B. A., Stromberg, P. C., Valli, V. E., Weisbrode, S. E., Yager, J., Heller, J. and Miller, R. (2011): Proposal of a 2-tier histologic grading system for canine cutaneous mast cell tumors to more accurately predict biological behavior. Vet. Pathol. 48, 147-155.

Kiupel, M., Webster, J. D., Kaneene, J. B., Miller, R. and Yuzbasiyan-Gurkan, V. (2004): The use of KIT and tryptase expression patterns as prognostic tools for canine cutaneous mast cell tumors. Vet. Pathol. 41, 371-377.

Macy, D. W. (1985): Canine mast cell tumors. Vet. Clin. North Am. Small. Anim. Pract. 15, 783-803.

Metcalfe, D. D., Baram, D. and Mekori, Y. A. (1997): Mast cells. Physiol. Rev. 77, 1033-1079.

Morini, M., Bettini, G., Preziosi, R. and Mandrioli, L. (2004): C-kit gene product (CD117) immunoreactivity in canine and feline paraffin sections. J. Histochem. Cytochem. 52, 705-708.

Northrup, N. C., Harmon, B. G., Gieger, T. L., Brown, C. A., Carmichael, K. P., Garcia, A., Latimer, K. S., Munday, J. S., Rakich, P. M., Richey, L. J., Stedman, N. L., Cheng, A. and Howerth, E. W. (2005): Variation among pathologists in histologic grading of canine cutaneous mast cell tumors. J. Vet. Diagn. Invest. 17, 245-248.

Passantino, L., Passantino, G., Cianciotta, A., Ribaud, M. R., Lo Presti, G., Ranieri, G. and Perillo, A. (2008): Expression of proto-oncogene c-kit and correlation with morphological evaluations in canine cutaneous mast cell tumors. Immunopharmacol. Immunotoxicol. 30, 609-621.

Patnaik, A. K., Ehler, W. J. and MacEwen, E. G. (1984): Canine cutaneous mast cell tumor: morphologic grading and survival time in 83 dogs. Vet. Pathol. 21, 469-474.

Phillips, V., Kelly, P. and McCluggage, W. G. (2009): Increased p16 expression in high-grade serous and undifferentiated carcinoma compared with other morphologic types of ovarian carcinoma. Int. J. Gynecol. Pathol. 28, 179-186.

Preziosi, R., Sarli, G. and Paltrinieri, M. (2004): Prognostic value of intratumoral vessel density in cutaneous mast cell tumors of the dog. J. Comp. Pathol. 130, 143-151.

Ranieri, G., Passantino, L., Patruno, R., Passantino, G., Jirillo, F., Catino, A., Mattioli, V., Gadaleta, C. and Ribatti, D. (2003): The dog mast cell tumour as a model to study the relationship between angiogenesis, mast cell density and tumour malignancy. Oncol. Rep. 10, 1189-1193. 
Rocco, J. W. and Sidransky, D. (2001): p16(MTS-1/CDKN2/INK4a) in cancer progression. Exp. Cell Res. 264, 42-55.

Strefezzi, R. F., Kleeb, S. R., Xavier, J. G. and Catao-Dias, J. L. (2009): Prognostic indicators for mast cell tumors. Braz. J. Vet. Pathol. 2, 110-121.

Theoharides, T. C. and Conti, P. (2004): Mast cells: the Jekyll and Hyde of tumor growth. Trends Immunol. 25, 235-241.

Webster, J. D., Yuzbasiyan-Gurkan, V., Kaneene, J. B., Miller, R., Resau, J. H. and Kiupel, M. (2006): The role of c-KIT in tumorigenesis: Evaluation in canine cutaneous mast cell tumors. Neoplasia 8, 104-111.

Witkiewicz, A. K., Knudsen, K. E., Dicker, A. P. and Knudsen, E. S. (2011): The meaning of p16ink4a expression in tumors: functional significance, clinical associations and future developments. Cell Cycle 10, 2497-2503.

Zemke, D., Yamini, B. and Yuzbasiyan-Gurkan, V. (2001): Characterization of an undifferentiated malignancy as a mast cell tumor using mutation analysis in the protoncogene c-KIT. J. Vet. Diagn. Invest. 13, 341-345.

Zemke, D., Yamini, B. and Yuzbasiyan-Gurkan, V. (2002): Mutations in the juxtamembrane domain of c-KIT are associated with higher grade mast cell tumors in dogs. Vet. Pathol. 39, 529-535. 